\title{
COMBINED HAZARD ANALYSES TO EXPLORE THE IMPACT OF LIQUID HYDROGEN FUEL ON THE CIVIL AVIATION INDUSTRY
}

\author{
CM Benson ${ }^{1}$, PG Holborn 1 , AM Rolt ${ }^{2}$, JM Ingram¹, E Alexander ${ }^{3}$ \\ ${ }^{1}$ London South Bank University, London, UK \\ ${ }^{2}$ Cranfield University, Bedfordshire, UK \\ ${ }^{3}$ Heathrow Airport Ltd, Hounslow, UK
}

\section{ABSTRACT}

Interest in green technology in aviation is increasing. To address environmental issues, novel fuels such as cryogenic liquid hydrogen $\left(\mathrm{LH}_{2}\right)$ are being explored, however there are safety concerns. This work combines safety studies to explore $\mathrm{LH}_{2}$ fuel safety for civil aviation. Preliminary hazard analyses (PHAs) (utilizing over 70 standards and guides) have been performed identifying possible $\mathrm{LH}_{2}$ hazards on-board aircraft. A PHA has also been produced, with industry stakeholder involvement, to understand the major concerns for $\mathrm{LH}_{2}$ use at airports.

Gaps in fundamental knowledge and $\mathrm{LH}_{2}$ technology have been identified, and two of these explored. Firstly, work has been started to understand the fundamental flammability of hydrogen in altitude conditions. Secondly, FLACS CFD modelling has been used to simulate large-scale $\mathrm{LH}_{2}$ pool releases to examine behavior and predict pool size, downwind flammable regions, and flammable mass clouds formed for different environmental conditions and release scenarios. This has identified significant effects of wind speed on buoyancy and flammable cloud travel which must be taken into account of any hydrogen fuel facility design.

This work (part of the EC funded ENABLEH2 project) is some of the first in over a decade to re-examine the safety of hydrogen propulsion in aircraft. This process has identified wide-ranging issues that must be addressed before hydrogen propulsion can be introduced in civil aviation.

Keywords: Hydrogen; Liquid Hydrogen; Safety; Hazards; Risk; Airports; Aircraft;

\section{NOMENCLATURE}

BLEVE Boiling Liquid Evaporating Vapor Explosion

CCC Climate Change Committee

CDM Clean Development Mechanism

CFD Computational Fluid Dynamics

$\mathrm{CO}_{2} \quad$ Carbon Dioxide
CORSIA Carbon Offsetting and Reduction Scheme for International Aviation

DDT Deflagration to Detonation Transition

EC European Commission

ENABLEH2 Enabling Cryogenic Hydrogen-based $\mathrm{CO}_{2}$-free Air Transport

$\mathrm{GH}_{2} \quad$ Gaseous Hydrogen

$\mathrm{H}_{2} \quad$ Hydrogen

ICAO International Civil Aviation Organization

$\mathrm{LH}_{2} \quad$ Liquid Hydrogen

NACA National Advisory Committee for Aeronautics

NASA National Aeronautics and Space

NOx $\quad$ Oxides of Nitrogen

PHA Preliminary Hazard Analysis

SRIA Strategic Research and Innovation Agenda

STP Standard Temperature and Pressure

\section{INTRODUCTION}

Civil aviation contributes to economic development that helps to raise living standards around the globe. However, the acceptability of further growth in air traffic is increasingly challenged because of its effects on the environment. Major concerns include the impact of engine exhaust emissions on global warming, on the ozone layer, and on human health.

Existing environmental legislation covers engine emissions of oxides of nitrogen (NOx), carbon monoxide, unburned hydrocarbons and particulates. Aero engines must meet specified limits for operation around airports, as these are pollutants that can aggravate respiratory diseases. However, the Advisory Council for Aviation Research and Innovation in Europe has set more ambitious goals for emissions reduction per passenger kilometer over entire flights. Targets in its Strategic Research and Innovation Agenda (SRIA) 'Flightpath 2050' include 75\% $\mathrm{CO}_{2}$ and $90 \%$ NOx emissions reductions by 2050 relative to new aircraft in service in year 2000 [1]. Other targets for aviation 
include arresting the growth in $\mathrm{CO}_{2}$ emissions by 2020 and halving that figure by 2050 .

Attention is now also shifting towards addressing the overall impact of aviation on climate, including radiative forcing by all greenhouse gas emissions, contrails and contrail-induced cloudiness. The energy efficiency of new commercial aircraft and engines continues to increase, but these ongoing improvements are expected to be outweighed by the projected growth in global air travel.

Therefore, to meet the $\mathrm{CO}_{2}$ emissions targets from 2021 onwards, the International Civil Aviation Organization (ICAO) is launching a Carbon Offsetting and Reduction Scheme for International Aviation (CORSIA) [2]. Offsetting aviation $\mathrm{CO}_{2}$ emissions is currently the most cost-effective means of meeting the $\mathrm{CO}_{2}$ targets and is permitted under the Clean Development Mechanism (CDM) established by the Kyoto Protocol. Airline flights wholly within the European Economic Area are already required to purchase carbon credits in the EU Emissions Trading Scheme (ETS).

The special report of the International Panel on Climate Change (IPCC) issued in October 2018 [3] advised that to limit global warming to $1.5^{\circ} \mathrm{C}$ above pre-industrial levels, net-zero $\mathrm{CO}_{2}$ emissions should be achieved by 2050 and that a $45 \%$ reduction from 2010 levels should be achieved by 2030. Similar reductions in non- $\mathrm{CO}_{2}$ emissions including methane and soot would also be required, and beyond 2050 it might still be necessary to achieve net-negative $\mathrm{CO}_{2}$ emissions, or take other measures to reduce radiative forcing, in order to avoid any further temperature increase.

The independent UK Committee on Climate Change (CCC) has endorsed the IPCC recommendations and advocated far reaching changes in energy use for heating, industry and transportation [4]. Replacing gas boilers with heat pumps and using electric road vehicles would significantly reduce $\mathrm{CO}_{2}$ emissions, but emissions from aviation were harder to reduce.

If aviation grows as anticipated in scenario studies commissioned by the CCC from Energy Systems Catapult [5], the proportion of average UK household $\mathrm{CO}_{2}$ emissions attributable to air travel could increase to $46 \%$ in 2050 , from $12 \%$ in 2017. This assumes net-zero UK emissions would be achieved and air travel only grows by $20 \%$. New carbon sinks must be created to compensate for UK household emissions in order to achieve net-zero $\mathrm{CO}_{2}$, e.g. by reforesting UK farmland or restoring wetlands [4].

If these targets are to be met, the cost of genuinely offsetting aviation's $\mathrm{CO}_{2}$ emissions in 2050 must rise significantly. This increases the incentive for the industry itself to reduce net $\mathrm{CO}_{2}$ emissions, despite the difficulty. The development of battery powered aircraft recharged by electricity generated by nuclear power or renewables only offers a partial solution; as these will only be feasible for ranges below about $1000 \mathrm{~km}$, even with the development of advanced $800 \mathrm{Wh} / \mathrm{kg}$ battery technology [6].

Alternative non-fossil fuels will be needed for longer-range aircraft in order to make significant reductions in $\mathrm{CO}_{2}$ emissions. These fuels may include biofuels derived from organic matter that has already extracted $\mathrm{CO}_{2}$ from the environment. Various feedstocks have been used to produce biofuels for aviation and these are generally blended 50/50 with kerosene to provide a drop-in replacement for Jet A-1. However, existing biofuels are expensive, and their production cycle is not entirely $\mathrm{CO}_{2}$-free.

Until now only a minute proportion of airline flights have used biofuels, and it will be very difficult to ramp-up production to cope with the potential demand. Nevertheless, drop-in replacement biofuels may be part of the solution, particularly for the existing fleet of commercial aircraft and engines.

Synthetic 'electro-fuels' are alternatives to biofuels. Hydrogen $\left(\mathrm{H}_{2}\right)$ and $\mathrm{CO}_{2}$ obtained by Direct Air Capture, or from carbonates in sea water, can be converted to hydrocarbons by means of the reverse water-gas shift reaction and the FisherTropsch processes. Several projects aim to bring down the cost of such fuels, but even with inexpensive electricity from renewable sources these fuels are likely to remain relatively expensive on account of the high capital costs involved.

Pure hydrogen is the simplest electro-fuel and is the most energy efficient to generate. It also has higher specific energy than any hydrocarbon fuel. In the long term the electrolysis of water may be the most economical way to produce large quantities of hydrogen, but it might also be generated via a series of thermo-chemical reactions driven by concentrated solar power or high-temperature nuclear reactors. Today most hydrogen is produced from natural gas with $\mathrm{CO}_{2}$ as a by-product. In the nearterm the $\mathrm{CO}_{2}$ may be sequestrated to make hydrogen production $\mathrm{CO}_{2}$ neutral. Alternatively, bio-methane might be used to produce the hydrogen. Sequestering, the $\mathrm{CO}_{2}$ could then make the overall fuel cycle $\mathrm{CO}_{2}$ net-negative to gain carbon credits for aviation.

Hydrogen is now being used as an ultra-clean fuel in trains, busses and other automotive applications. It is also used by fuel cells in a few experimental light aircraft. In these applications the hydrogen is stored as a highly compressed gas $\left(\mathrm{GH}_{2}\right)$, but its low density means that the pressure vessels used to store it are very much heavier than the gas they contain. This may be just acceptable for very efficient aircraft with ranges of up to about $2000 \mathrm{~km}$. However, liquid hydrogen $\left(\mathrm{LH}_{2}\right)$ has higher density, so much larger quantities can be stored at low pressure in lighter tanks. This gives $\mathrm{LH}_{2}$-fuelled aircraft the potential for unlimited point-to-point range. For these reasons, liquid hydrogen has long been considered an attractive fuel for future commercial aircraft.

\section{HISTORY}

$\mathrm{LH}_{2}$-aircraft research has proceeded intermittently for more than sixty years. In 1957 the NACA flew a twin-engine B-57 with a Curtis Wright J-65 turbojet modified to run on hydrogen, but it only switched to hydrogen at cruise. $\mathrm{LH}_{2}$ was contained in one wing-tip tank which was initially pressurized using helium gas from the other wing-tip tank. (Using helium to pressurize the hydrogen tanks would be unacceptable in future commercial aircraft because helium is a finite and non-renewable resource.)

Pratt \& Whitney began development of the 'Model 304' afterburning turbojet with an 'expander cycle' where a geared fan was driven by a hydrogen turbine, but the proposed application, the Mach 2.5 Lockheed CL-400 reconnaissance aircraft, was 
cancelled and the engine development ceased. Other early US studies considered hypersonic aircraft where cryofuels would have been essential for airframe and engine cooling.

In the 1970s NASA funded studies into hydrogen-fueled aircraft at Lockheed and elsewhere. Based on NASA reports, the Lockheed studies were described in detail by Brewer [7]. These studies considered a scenario where oil was in short supply and aircraft fuels would be produced from coal. This meant synthetic kerosene, methane and hydrogen would have similar costs for a given energy content. Today it is considered unlikely that oil supplies will run-out in the $21^{\text {st }}$ century, so any transition to cryofuels will only be driven by environmental considerations.

In the USSR, Tupolev researched subsonic transport aircraft applications. In the late 1980s the Tu-155 flew with one engine running on $\mathrm{LH}_{2}$ and later it was modified to run on LNG or methane. Then about 20 years ago Airbus led the 'Cryoplane' project which looked at a wide range of subsonic $\mathrm{LH}_{2}$ aircraft designs. The 400-passenger long-range study aircraft had significantly reduced maximum take-off weight relative to a kerosene fueled design but had a big increase in empty weight on account of its large hydrogen tanks [8]. It was very similar to the earlier Lockheed design. However, projecting aircraft and engine technologies forward to 2050, it is anticipated that moreefficient aircraft and engine designs should significantly reduce the amount of $\mathrm{LH}_{2}$ required for the same mission.

The Cryoplane study was not immediately followed-up because of the cost of $\mathrm{LH}_{2}$ and the lack of any strong imperative to switch to a radically different fuel. However, climate change is now seen as a more urgent issue and threat to business-as-usual aviation growth and technology development. Also, given recent dramatic reductions in the cost of electricity produced by solar panels and wind turbines, it is now more credible that $\mathrm{LH}_{2}$ will become an economically viable electrofuel for future aircraft.

However, there are still concerns around the safety of liquid hydrogen, and, as with any new technology, particularly in a safety-critical industry like aviation, a significant amount of work is needed to integrate it safely into the existing industry and infrastructure.

This work brings together a series of studies carried out to examine the impact that hazards associated with liquid hydrogen will have on the civil aviation industry have as part of the ENABLEH2 project. The gaps in technology and knowledge, which currently serve to act as a barrier to hydrogen adoption for the industry-at-large, have been identified, and work has begun to start to address these areas of need.

\section{HYDROGEN SAFETY}

A switch to a cryogenic fuel, such as liquid hydrogen or methane, has significant implications for the aviation industry: for aircraft manufacturers, fuel producers and suppliers and the supporting infrastructure at airports. Currently fuel for civil aviation is generally the kerosene-based liquid Jet-A, Jet-A1 or similar; a liquid that is often supplied from multiple pipelines in a network to maintain high volumes needed by airports with the required redundancy. Cryogenic liquid hydrogen would require significantly different storage (at $\left.-250^{\circ} \mathrm{C}\right)$. Options for fuel supply that could be explored are piping in as a gas and liquefying at the airport, piping in the liquid itself, or possibly production and liquefaction on-site. However, aside from the very low temperature hydrogen has properties that are quite different to those of hydrocarbon liquid fuels.

Hydrogen is far more buoyant and prone to dispersion than hydrocarbon fuels. This means that systems for $\mathrm{LH} 2$ and $\mathrm{GH} 2$ may need to be very different to current systems, designed to deal with leaks of liquid fuels that fall downwards, and vaporize at a low level. They will need to meet requirements to deal with a rapidly vaporizing fuel which will rise upwards far more quickly.

Hydrogen also has wide flammability envelope and relative ease of ignition. The flash point of Kerosene is $38-66^{\circ} \mathrm{C}$. It won't form a flammable atmosphere above the liquid surface until reaching that temperature, and when it does the flammable region is approx. $0.5-5 \%$ in air. While any release of hydrogen has the capability to form an explosive atmosphere and can be ignited at approx. $4-75 \%$ in air at STP.

Hydrogen flames have a lower effective radiative output due to the release of thermal radiation being primarily due to excited water molecules (rather than $\mathrm{CO} 2$ and soot as is the case with hydrocarbons) and the effect of humidity in the surrounding atmosphere which (being composed of water molecules) can absorb a significant fraction of the radiation produced [9].

This differing behavior of hydrogen relative to the more conventional hydrocarbon fuels means that designs, processes and standards are all likely to have to change to support its introduction.

\subsection{Liquid Hydrogen Safety}

Liquid hydrogen use and safety have been examined reasonably extensively for use across industry with a number of studies resulting to enable safe use $[10,11,12]$. Few studies have examined this fuel for use in aviation. Brewer (1991) [7] examined the safety on liquid hydrogen in terms of crash survivability showing that the dispersion in a catastrophic event would provide safety benefits over Jet fuel. There is also some benefit from lower thermal output should the fuel catch fire Khandelwal et al. (2013) [13].

Schmidtchen et al. (1997) [15], also examine hydrogen safety for both aircraft and airports. While they identify some areas that still require engineering and science solutions and specific areas of concern for designers, they determine that the use of the fuel should not be dismissed on the basis of safety. Some other studies have examined some specific components. The importance of fuel tank design and placement has also been discussed as a key safety design $[13,16]$. All of these studies have concluded that the safety of the aviation industry should not be adversely affected by hydrogen fuel introduction, if the relevant standards and technology are developed. Benson et al (2019) [14] carried out an extensive PHA process for liquid hydrogen propulsion systems, highlighting a significant number of hazards, and more importantly the gaps that are still acting as barriers to this technology introduction, from both fundamental science and engineering technology development perspectives. 
TABLE 1: A SUMMARY OF MAJOR HAZARDS ASSOCIATED WITH LIQUID HYDROGEN SYSTEMS ON BOARD AIRCRAFT (Benson et al 2019 [14])

\begin{tabular}{|c|c|c|}
\hline $\begin{array}{l}\text { Hazard } \\
\text { categories }\end{array}$ & Storage & $\begin{array}{l}\text { Heat management/ } \\
\text { transport }\end{array}$ \\
\hline Temperature & $\begin{array}{l}\text { Cryogenic hazards } \\
\text { to people and } \\
\text { equipment, } \\
\text { expansion/ damage } \\
\text { effects from heat } \\
\text { input }\end{array}$ & $\begin{array}{l}\text { Cryogenic hazards to } \\
\text { people/equipment, } \\
\text { expansion/ damage } \\
\text { effects from heat } \\
\text { input, the formation } \\
\text { of highly flammable } \\
\text { hydrogen-oxygen or } \\
\text { oxygen 'slush' } \\
\text { around leaks/ at cold } \\
\text { surfaces. }\end{array}$ \\
\hline Pressure & $\begin{array}{l}\text { Expansion from } \\
\text { heat increases, } \\
\text { backflow of } \\
\text { contaminated/ } \\
\text { higher pressure } \\
\text { stream }\end{array}$ & $\begin{array}{l}\text { Expansion from heat } \\
\text { increases, ingress of } \\
\text { air forming a } \\
\text { flammable } \\
\text { atmosphere }\end{array}$ \\
\hline Chemical & $\begin{array}{l}\text { Contamination } \\
\text { causing blockages } \\
\text { or oxidation, ortho- } \\
\text { para conversion } \\
\text { causing increased } \\
\text { expansion, leaks of } \\
\text { flammable/ } \\
\text { cryogenic } \\
\text { materials, } \\
\text { compatibility of } \\
\text { materials (e.g. } \\
\text { embrittlement). }\end{array}$ & $\begin{array}{l}\text { Contamination } \\
\text { causing blockages or } \\
\text { oxidation, ortho-para } \\
\text { conversion causing } \\
\text { increased expansion, } \\
\text { leaks of flammable/ } \\
\text { cryogenic materials, } \\
\text { compatibility of } \\
\text { materials (e.g. } \\
\text { embrittlement). }\end{array}$ \\
\hline Mechanical & $\begin{array}{l}\text { System damage } \\
\text { from sloshing, } \\
\text { Impact, vibration, } \\
\text { and strain }\end{array}$ & $\begin{array}{l}\text { System damage from } \\
\text { thermoacoustic } \\
\text { oscillation of liquid/ } \\
\text { gas fuel, fluid- } \\
\text { hammer, impact, } \\
\text { vibration and strain }\end{array}$ \\
\hline Leak/spill & $\begin{array}{l}\text { Cryogenic hazards } \\
\text { to people and } \\
\text { equipment, } \\
\text { flammable hazards } \\
\text { from the formation } \\
\text { of a flammable } \\
\text { atmosphere }\end{array}$ & $\begin{array}{l}\text { Cryogenic hazards to } \\
\text { people and } \\
\text { equipment, } \\
\text { flammable hazards } \\
\text { from the formation of } \\
\text { a flammable } \\
\text { atmosphere }\end{array}$ \\
\hline Physiological & $\begin{array}{l}\text { Burns (cold, heat), } \\
\text { asphyxiation }\end{array}$ & $\begin{array}{l}\text { Burn (cold, heat), } \\
\text { asphyxiation }\end{array}$ \\
\hline
\end{tabular}

Table 1 summarizes the hazards identified in that work related directly to liquid hydrogen. As liquid hydrogen moves through the propulsion system it is gasified. If fuel escapes from the liquid system, it is highly likely it will evaporate on release. As such Table 2 summarizes the hazards related to gaseous hydrogen that will be relevant to LH2 in those scenarios.
TABLE 2: A SUMMARY OF MAJOR HAZARDS ASSOCIATED WITH GASEOUS HYDROGEN SYSTEMS ON BOARD AIRCRAFT (Benson et al 2019 [14])

\begin{tabular}{|c|c|c|}
\hline $\begin{array}{l}\text { Hazard } \\
\text { categories }\end{array}$ & $\begin{array}{l}\text { Heat management/ } \\
\text { transport }\end{array}$ & Combustion \\
\hline Temperature & Properties effect & Properties effect \\
\hline Pressure & $\begin{array}{l}\text { Expansion from heat } \\
\text { increases, ingress of } \\
\text { air forming a } \\
\text { flammable } \\
\text { atmosphere }\end{array}$ & $\begin{array}{l}\text { Importance of } \\
\text { maintaining } \\
\text { temperature to } \\
\text { support combustion }\end{array}$ \\
\hline Chemical & $\begin{array}{l}\text { Leaks of flammable } \\
\text { materials, and } \\
\text { compatibility of } \\
\text { materials (e.g. } \\
\text { embrittlement). }\end{array}$ & $\begin{array}{l}\text { Leaks of flammable } \\
\text { materials, and } \\
\text { compatibility of } \\
\text { materials (e.g. } \\
\text { embrittlement). }\end{array}$ \\
\hline Mechanical & $\begin{array}{l}\text { System damage from } \\
\text { impact, vibration, } \\
\text { strain }\end{array}$ & $\begin{array}{l}\text { System damage from } \\
\text { impact, vibration, } \\
\text { strain, and } \\
\text { thermoacoustic } \\
\text { oscillation in } \\
\text { combustors }\end{array}$ \\
\hline Leak/ spill & $\begin{array}{l}\text { Flammable hazards } \\
\text { from the formation } \\
\text { of a flammable } \\
\text { atmosphere }\end{array}$ & $\begin{array}{l}\text { Flammable hazards } \\
\text { from the formation of } \\
\text { a flammable } \\
\text { atmosphere }\end{array}$ \\
\hline Physiological & Burn (hot) & Burn (hot) \\
\hline $\begin{array}{l}\text { Fire/ } \\
\text { Explosion }\end{array}$ & $\begin{array}{l}\text { Confined explosion, } \\
\text { danger of } \\
\text { deflagration to } \\
\text { detonation transition } \\
\text { in event of ignition }\end{array}$ & $\begin{array}{l}\text { Flameout risk and } \\
\text { ensuring re-ignition, } \\
\text { Danger of } \\
\text { deflagration to } \\
\text { detonation transition } \\
\text { in event of ignition }\end{array}$ \\
\hline
\end{tabular}

A gap analysis based on this assessment identified the following areas of need (Benson et al 2019 [14]):

- Effect of aircraft motion (vibration, strain) on $\mathrm{H}_{2}$ systems

- Effect of flight profile \& aviation conditions (pressure/ temperature) on $\mathrm{H}_{2}$ systems

- $\mathrm{H}_{2}$ Flammability in aviation conditions

- Ignition of $\mathrm{H}_{2}$ by different stimuli in aviation conditions

- Fuel tank design and protection

- Danger of deflagration to detonation transition (DDT)

- Prevent flameout and ensuring re-ignition

- Fire and explosion protection for the aircraft (fire suppression, inerting, ventilation, venting).

The ENABLEH2 project intends to examine and fill as many of these gaps as possible.

\subsection{Fundamental studies in hydrogen flammability}

A serious knowledge gap identified by the initial literature survey and PHA process is the definition of ignition and flammability characteristics for hydrogen under various aviation operating conditions. 
The flammability of hydrogen in low temperatures has been studied to a reasonable degree due to the use of cryogenic hydrogen in industry [12]. Wierzba et al (1992) [17] extended work examining hydrogen flammability at temperatures from $-60^{\circ} \mathrm{C}$ to $-100^{\circ} \mathrm{C}$, and recently Panda \& Hecht (2017) [18] explored ignition and flammability of cryogenic hydrogen exploring jet flame behavior for a range of release scenarios from $37 \mathrm{~K}$ to $295 \mathrm{~K}$. Kuznetsov et al (2015) also looked at the effects of a variety of test parameters [19].

Relatively few studies have examined the flammability of hydrogen in low-pressure environments. Rehn (2014) [20] examined the flammability of hydrogen in a $20 \mathrm{~L}$ vessel, at air pressures from atmospheric down to approx. 186 mbar (replicating pressures found at altitudes of 40,000 ft), finding a general widening of a flammability envelope with decreasing pressures. With a $3 \%$ pressure rise criterion, the lower flammability limit (LFL) was found to be $3.89 \%$ hydrogen at pressures replicating 40,000 feet (reduced from $4.70 \%$ hydrogen at atmospheric pressure). The upper flammability limit (UFL) was found to be $78.18 \%$ hydrogen at sea level, decreasing to $76.87 \%$ at 40,000 feet. Kuznetsov et al (2012) [21] examined hydrogen flammability in an $8 \mathrm{~L}$ vessel, at pressures between 25 mbar and 1000 mbar, with upper flammability limits changing to $78 \% \mathrm{H} 2$ between 200 mbar and 500 mbar, although for an initial pressure of 1000 mbar it was found to be only $76 \%$. Some work had been previously performed by Jones (2009) [22] however the spark energy used (at $5000 \mathrm{~V}$ ) was far below the higher energies used in, for example, explosion standard tests [23] and other studies, and are thus not comparable.

Even less work appears to have been done investigating the fundamental flammability and ignition properties of hydrogen under the combined circumstances of low pressure and low temperature. In fact, the authors of this work cannot locate any publication studying this subject. And yet, in order to understand the behavior of hydrogen and the risks associated with it, it is absolutely necessary that these properties are defined. The information is needed to inform ignition prediction, and explosion prevention and mitigation, assessment and strategies.

The extreme conditions found at altitude will be explored by the authors of this work, in a novel experimental rig as part of the EC ENABLEH2 project over the next 2 years. It will operate at down to 150 mbar pressure and $-50^{\circ} \mathrm{C}$. The work will explore flammability fundamentals such as flame speed, minimum ignition energies, and other key safety parameters.

\subsection{Hydrogen at airports}

For airports there have been very few studies examining liquid hydrogen safety. The use of hydrogen in the gaseous form has been relatively well examined as airports expand their use of hydrogen technologies for ground-based operations [24, 25, 26]. The safety of liquid hydrogen at airports has also been examined from a storage perspective to support these activities [27], but the volume involved was substantially less than that needed to support civil aviation. The work around airports and liquid hydrogen generally focuses on fuel supply, without a safety focus however Schmidtchen et al. (1997) [15] performed a safety examination of airports, settling on liquefaction at airports with underground pipes supplying aircraft. While this piped approach may be sensible in the long term, a transitional period might not allow this process, and fueling might have to be performed by tanker vehicles, meaning different refueling scenarios and risks. They make an excellent point in that odorizing additives would likely be extremely difficult to use at the cold temperatures (due to solidification) so alternative methods would be needed for detection. They also identify further work being needed to explore the scale of storage and leaks. The Preliminary hazard analysis [28] method has been applied in this paper to airport safety, to explore the use of liquid hydrogen at airports, and the alterations and mitigations that might be needed to enable this cryogenic and flammable fuel to be used in this complex and fast-moving environment. The method and results can be found later in this paper.

It is also necessary to improve understanding of the largescale hazards that could be posed by liquid hydrogen in aviation accident scenarios, such as leaks from airport fuel storage tanks. Some large-scale trials have been performed examining dispersion [19 29, 30] but only cover a restricted range of scenarios. Recent advances in modelling capability and improved validation for hydrogen releases, enable the use of state-of-the-art dispersion/explosion CFD software to be used to examine a range of release scenarios. FLACS 3D CFD software has integrated modules for ventilation/dispersion, and explosion modelling, with a good degree of accuracy/validation for modelling gaseous explosion over a wide range of scenarios and particularly for modelling hydrogen releases/explosions (underpinned an extensive publication record in this area, including FLACS application to LH2 releases [31]). The FLACS CFD code has therefore been applied in this work to model largescale liquid hydrogen spills and associated flammable gas cloud behavior (e.g. the effect of wind speed and ground substrate type on the extent of the flammable cloud generated). However further work is needed to use these validated tools to explore scenarios at airports, and around production and storage installations.

\section{METHODOLOGY}

The following section details work carried out in order to assess hazards associated with hydrogen fuel use at airports. For the first part of this work a PHA process has been used to identify hazards when liquid hydrogen fuel is assessed across a range of categories, chosen by aviation industry, fire and hydrogen professionals. The gaps in knowledge and technology were also highlighted by this process. The second part of the work starts to develop one of the identified hazards and knowledge gaps; the lack of understanding on large scale hydrogen release and dispersion. This gap is being explored as it links a number of different hazard scenarios for storage and production installations, and aircraft tank breach through collision or crash, as well as aiding emergency responders to understand the behavior of hazards they may face in a hydrogen release scenario. 


\subsection{Preliminary Hazard Analysis work for liquid hydrogen use at airports}

The PHA is often the first stage of a risk assessment process. As it is performed in the early stages of a project it can often form the basis for later risk assessment methods. Applying the US Department of Defense [28] approach, a panel of hydrogen experts and aviation/ airport stakeholders was convened including:

- Airport operator

- Fire \& rescue service

- Liquid hydrogen provider

- Aircraft \& engine manufacturers

- Aviation system design experts

Following discussions with the airport operator, Heathrow Airport Ltd, these experts were asked to assess a series of hazards under the following categories:

- Storage and on-site generation

- Firefighting

- Fueling (and ground transport)

- Taxiing

- Take-off and landing

A preliminary hazard list (PHL) was constructed by examining existing hazards, and the operational requirements that might be affected by the switch from hydrocarbon jet fuel to LH2. In this case, hazards were judged as being anything that would affect the airport in terms of danger to life/ persons and property, or a significant interruption to airport operations. Scores ranged from 1 (extremely unlikely/ low impact) to 5 (Highly likely/ catastrophic).

Following these assessments, where scores had been given, the overall risk factor was calculated by multiplying the severity and likelihood scores together. Where a range was given upper and lower risk factors were calculated. The results of these calculations are show later in Figure 2.

\subsection{FLACS Liquid Hydrogen Pool Spill Simulations}

The numerical simulations were performed using the FLACS CFD model. FLACS was originally developed in the 1980 and 90s for use in the Oil and Gas industry. It provides capabilities for carrying-out safety studies by simulating accident scenarios involving fluid flow behavior in complex 3D geometries by modelling flammable gas hazard effects such as the dispersion of flammable gases, gas explosions and pool/jet fires.

FLACS is a structured Cartesian grid, finite volume CFD code. The code solves conservation equations for mass, momentum, enthalpy, mass fraction of chemical species, turbulent kinetic energy and dissipation rate of turbulent kinetic energy [32]. A standard $\mathrm{k}-\varepsilon$ turbulence model is utilized incorporating modifications for generation of turbulence behind sub-grid obstacles and turbulent wall functions. FLACS employs the Porosity/Distributed Resistance method to model the turbulence generated by sub-grid scale objects. This allows for the efficient simulation of gas dispersion behavior in complex geometries using relatively coarse numerical grids. Atmospheric boundary layer flows are modelled in FLACS by introducing profiles for wind velocity, temperature and turbulence on the flow inlet boundaries [32]. Buoyancy effects are accounted for by introducing additional source terms in the momentum and turbulence model equations. The model has been tested for a wide variety of scenarios including buoyant and dense gas releases [33,34].

The FLACS pool model allows the deposition and spread of a pool of liquid from a spill onto the ground to be simulated and the release source term to the gas dispersion model to be calculated. The model was originally developed for use with LNG spills but has also been applied to liquid hydrogen releases. The behavior of the spreading liquid pool is approximated by solving the shallow-water equations on a two-dimensional Cartesian grid along the ground and assuming that the pool properties are uniform across the height of the pool. Middha et al. [35] used the FLACS CFD (pool) model to simulate LH2 pool spread and gas cloud dispersion behavior for the NASA White Sands Experiments [36]. On the basis of their study, the authors concluded that the FLACS pool model provides an efficient and accurate tool for investigating accidental release scenarios involving cryogenic liquids such as LH2.

\section{Simulation details}

The initial validation simulations were performed on a domain $200 \mathrm{~m} \times 60 \mathrm{~m} \times 80 \mathrm{~m}$ in the $\mathrm{X}, \mathrm{Y}$ and $\mathrm{Z}$ directions (-30 $\mathrm{m}$ to $170 \mathrm{~m},-30 \mathrm{~m}$ to $30 \mathrm{~m}, 0$ to $80 \mathrm{~m}$ ). The grid employed had a total of 177,284 cells $(82 \times 47 \times 46$ cells). In the pool region a grid cell size of $0.5 \mathrm{~m}$ was used in the $\mathrm{X}$ and $\mathrm{Y}$ directions and $0.12 \mathrm{~m}$ in the $\mathrm{Z}$ direction. Outside this region the grid cell size was increased, by using an expansion factor of 1.2 , and setting a maximum grid cell size of $4 \mathrm{~m}$. The mesh employed in the FLACS simulations is shown in Figure 1. For some simulations the size of the domain and number of grid cells was increased, in the X-direction, to $400 \mathrm{~m} \times 60 \mathrm{~m} \times 80 \mathrm{~m}(82 \times 47 \times 46-285,384$ cells) to allow the simulation of higher wind speeds upon flammable cloud dispersion behavior.

The ambient temperature was set to $15^{\circ} \mathrm{C}$. The ground roughness length for the wind profile was set to $3 \mathrm{~mm}$. The Pasquill stability class was set to class $\mathrm{F}$ - stable (produced best match in Middha et al. [35]) The pool model spill point was set at the origin $(0,0,0)$. The inlet boundary (type WIND) was defined at $30 \mathrm{~m}$ upwind of this point. A pool fence, $0.6 \mathrm{~m}$ high, was defined at radius of $4.25 \mathrm{~m}$ from the spill point. The thermal conductivity and thermal diffusivity of the ground used in the pool model were set to $3.72 \mathrm{~W} / \mathrm{m} . \mathrm{K}$ and $1.45 \times 10-6 \mathrm{~m} 2 / \mathrm{s}$, to replicate the thermal properties of wet coarse sand.

The pool release was started after 10 seconds of simulation time to allow the wind field to become established. Liquid hydrogen in the pool model was released at $9.5 \mathrm{~kg} / \mathrm{s}$ for a duration of $38 \mathrm{~s}$. As a conservative assumption with regard to formation of liquid pool and subsequent dispersion behavior, it was further assumed that all of the LH2 release was deposited into the LH2 pool and that the effects of flash vaporization were neglected [35]. 


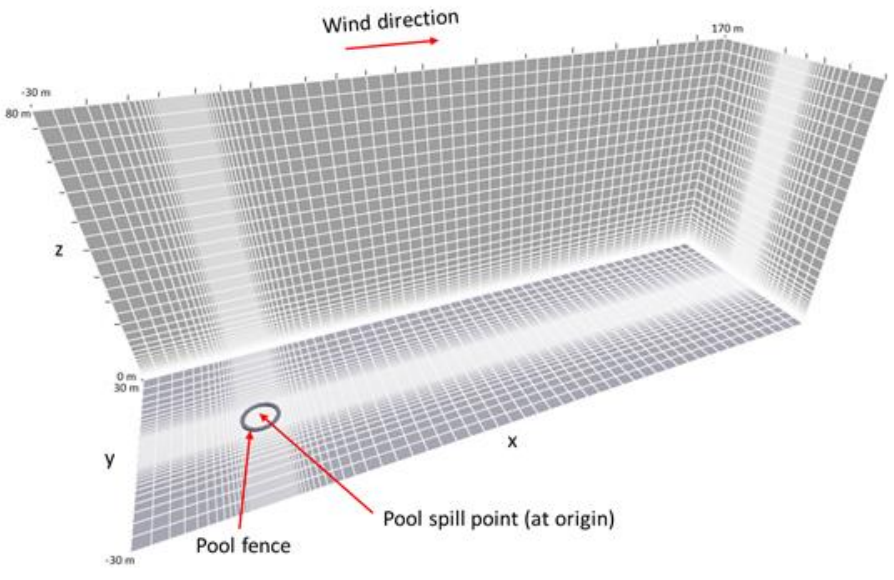

FIGURE 1: AN EXAMPLE OF THE GEOMETRIC MODEL AND MESH USED IN THE FLACS SIMULATIONS.

\section{RESULTS AND DISCUSSION}

This section details the result from the Preliminary Hazard Analysis (PHA) activity and the simulation work done to explore the hazard scenario of a large scale liquid hydrogen tank/ system breach.

\subsection{Preliminary Hazard Analysis work for liquid hydrogen use at airports}

The following sections describe the major conclusions of the PHA activity including a broad description of hazard scores, mitigations and gaps identified.

Figure 2 shows the risk factors for the hazards (the product of severity and likelihood scores, where scores, or a range of these, could be assigned by industry experts). Error bars show the range of the risk factors calculated. It is clear that postmitigation the risk factor for the majority of hazards falls, with experts believing it is possible to reduce the risk in these scenarios. However, the size of the error bar tends to increase due to the lack of certainty, or existing technology and information on the engineering needed to enable the safe introduction of the changes or mitigations. The most serious concerns, and scenarios with the highest risk factor (both preand post-mitigations), are in firefighting. Storage and on-site generation category shows the most significant drop between pre- and post- mitigation assessment. This is due to confidence of industry professionals that existing industry methods can be used, though all of the post-mitigation risk factors have a reasonably large range. The following sections contain a summary of each category for assessment.

\section{Storage and on-site generation}

On storage, the concerns featured around the interrelated hazards of fire, explosion cryogenic, over-pressure and leaks. Human error, integrity of asset, external impact, loss of power, control failure and sabotage were identified as possible causes of the events. It was recognized that all of these hazards could result in severe or catastrophic events, though in almost all cases the likelihood was unlikely (score 1 or 2). Prevention strategies explored were maintenance (particularly in relation to overpressurization) emergency shutdown, separation, and improved designs and operating procedures.

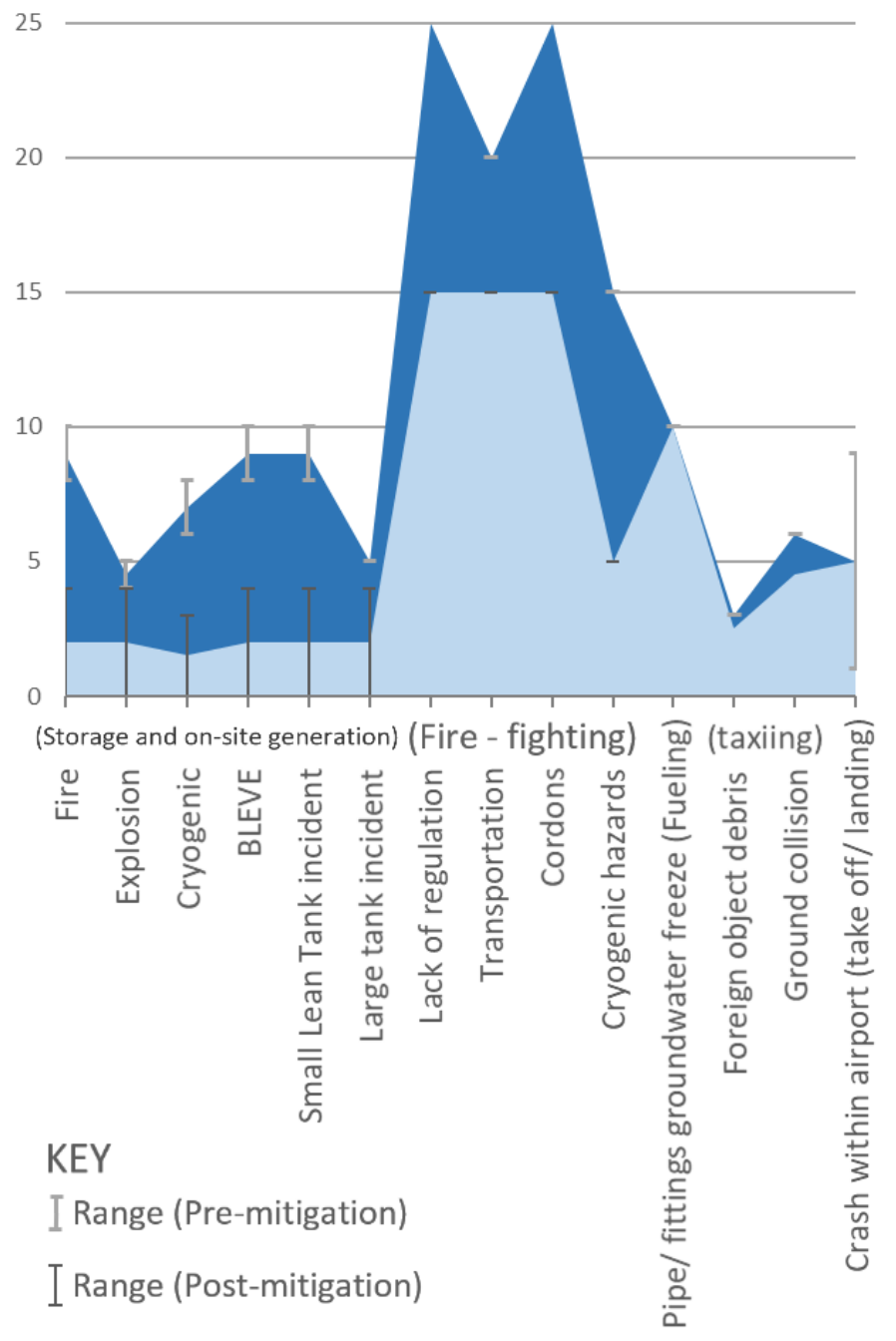

- Risk Factor (pre-mitigation)

Risk Factor (post-mitigation)

BLEVE =Boiling Liquid Evaporating Vapor Explosion .

FIGURE 2: A GRAPH SHOWING THE COMBINED RISK FACTORS FOR HAZARD IN USING LIQUID HYDROGEN FUEL AT AIRPORTS.

The further work identified was the need to define storage size, the feasibility of on-site hydrogen generation and/or liquefaction, and a need to look at catastrophic hydrogen releases with detailed risk assessment work. Industry professionals judged that with existing mitigations, and re-engineered systems, they were confident event likelihood could be reduced even further (0-1) with some reduction in severity outcomes (4). 
TABLE 3: SEVERITY AND LIKELIHOOD SCORES FOR HAZARD SCENARIOS IDENTIIFED IN A PRELIMINARY HAZARD ANALYSIS EXCERCISE

\begin{tabular}{|c|c|c|c|c|}
\hline \multirow[b]{2}{*}{ Hazard } & \multicolumn{2}{|c|}{$\begin{array}{c}\text { Before } \\
\text { prevention, } \\
\text { alteration, } \\
\text { mitigation }\end{array}$} & \multicolumn{2}{|c|}{$\begin{array}{c}\text { After } \\
\text { prevention, } \\
\text { alteration, } \\
\text { mitigation }\end{array}$} \\
\hline & $\mathbf{S}$ & $\mathbf{L}$ & $\mathbf{S}$ & $\mathbf{L}$ \\
\hline \multicolumn{5}{|l|}{ Storage and on-site generation } \\
\hline Fire & $4-5$ & 2 & 4 & $0-1$ \\
\hline Explosion & $4-5$ & 1 & 4 & $0-1$ \\
\hline Cold & $3-4$ & 2 & 3 & $0-1$ \\
\hline $\begin{array}{l}\text { Boiling Liquid Evaporating Vapor } \\
\text { Explosion (BLEVE) risk }\end{array}$ & $4-5$ & 2 & 4 & $0-1$ \\
\hline Small Lean Tank $\mathrm{LH}_{2}$ incident & $4-5$ & 2 & 4 & $0-1$ \\
\hline Large tank $\mathrm{LH}_{2}$ incident & 5 & 1 & 4 & $0-1$ \\
\hline \multicolumn{5}{|l|}{ Firefighting } \\
\hline Lack of regulation & 5 & 5 & 5 & 3 \\
\hline Transportation & 5 & 4 & 5 & 3 \\
\hline Cordons & 5 & 5 & 5 & 3 \\
\hline Cryogenic liquid & 5 & 3 & 5 & 1 \\
\hline Flammable atmosphere & 5 & 4 & - & - \\
\hline \multicolumn{5}{|l|}{ Fueling (and ground transport) } \\
\hline Major release during refueling & 5 & 2 & - & - \\
\hline $\begin{array}{l}\text { Minor \& short duration release during } \\
\text { refueling }\end{array}$ & 2 & 5 & - & - \\
\hline Minor \& long release during refueling & $1-3$ & 4 & - & - \\
\hline $\begin{array}{l}\text { Pipe \& fittings freeze collected/ } \\
\text { ground water }\end{array}$ & 2 & 5 & 2 & 5 \\
\hline $\begin{array}{l}\text { Gas release though Pressure Safety } \\
\text { Valve }\end{array}$ & 3 & 2 & - & - \\
\hline Gas cloud ignition & $2-4$ & $2-4$ & - & - \\
\hline \multicolumn{5}{|l|}{ Taxiing } \\
\hline Major Fuel tank leak & $3-5$ & 2 & - & - \\
\hline Small leak from foreign object strike & $2-4$ & 1 & $2-3$ & 1 \\
\hline Small leak from ground collision & $2-5$ & $1-2$ & $2-5$ & 1 \\
\hline \multicolumn{5}{|l|}{ Take-off and landing } \\
\hline Crash within airport & 5 & 1 & 5 & 1 \\
\hline
\end{tabular}

$\mathrm{S}=$ Severity. $\mathrm{L}=$ Likelihood. - = an area where such a level of further work is required that experts could not assign scores.

\section{Firefighting}

Firefighting was an area where the most change appeared to be needed. Currently airports are assessed based on the calculated need for firefighting facilities (for example amount of foam). Fire-fighting professionals pointed out this entire system of safety, risk assessment and regulatory classification and controls would have to change. Hazard areas identified were lack of regulation, transportation concerns, cordon requirements, cryogenic and flammable hazards. All hazards were judged to be capable of catastrophic outcomes (score 5) with likelihood scores of 3-5. A number of the mitigations or changes in practice were revealed to already exist (e.g. firefighting practices for dealing with cryogenic materials and the practically-invisible hydrogen flames, such as safe storage, respiratory protection, thermal imaging) however the level of mitigation needed resulted in likelihood scores being reduced to only 3 due to the amount of work still required to fill the gaps and integrate identified mitigations into existing fire and rescue organizations (severity scores remain unchanged as the event may still be catastrophic). In terms of future work and changes it was judged by the experts that everything in terms of fire service operation would be affected. Firefighting measures exist for liquid hydrogen, however the current processes require overhaul in relation to training, protective and firefighting equipment, cordons, and fire protection. A new regulatory regime is needed to be developed for the use of hydrogen at airports, and for the assessment of the airport requirements in terms of fire cover.

\section{Fueling (and ground transport)}

The major hazards here were identified as cryogenic and flammable in relation to an unwanted release. A number of modes were identified including mechanical failure, full-bore rupture, impact (on pipe, tank, aircraft), operator error, malfunctioning safety valves, a long stay on tarmac (leading to boil-off) and poor design. Possible negative outcomes included physiological dangers to airport staff and users, local damage to vehicles and infrastructure, wider damage to infrastructure, and operational disruption. Freezing Pipes (to ground) or valves were judged as particularly likely hazards that need to be designed out. Severity ranged anywhere from 1 to 5 depending on the size of the leaks. Prevention and mitigation actions included welldesigned procedures, possible use of robots or remote refueling, protective equipment leak detection, fire-detection systems and good designs of pipes, tanks and aircraft. This was such a high level of further work that most hazards were not given a severity or likelihood score on the reassessment.

\section{Taxiing}

Again, general leak hazards, with increased hazard in the case of fire, was the primary concern. Generally, the likelihood of events was judged to be relatively unlikely ( 1 or 2 ) with severity depending on whether a fire occurred, when a catastrophic score of 5 was given. Prevention and mitigations were listed as robust tank design and protection, local fire suppression systems and control of ground traffic. Post these mitigations, scores were unchanged without the new systems designs being in existence yet.

\section{Take-off and landing}

The only concern was a form of crash or heavy landing at the airport. The severity of the incident was judged to be a 5 , with a likelihood as 1 . This was unchanged, with mitigations largely due to the likely disruption to the airport, however specific mitigations were listed to introduce cordons and to assess whether evacuation would be the best option in such scenarios, i.e. depending on whether hydrogen had escaped, passengers remaining on the aircraft could be safer than evacuating towards the hazard. Hydrogen's rapid dispersion and high buoyancy could be a benefit in this scenario. Further risk analysis work is needed on crash-worthiness, leaks and large volume hydrogen releases.

One area identified in both on-board systems and airport PHA as requiring further work was the analysis of releases of large volumes of liquid hydrogen. The following section details work that has been performed to examine this. 


\subsection{FLACS Liquid Hydrogen Pool Spill Simulations}

In order to improve understanding of the large-scale hazards that could be posed by LH2 in aviation accident scenarios, such as leaks from airport fuel storage tanks, numerical simulations have been performed to model the effect of wind speed and ground substrate type on the extent of the flammable cloud generated by large-scale $\mathrm{LH} 2$ pills and the associated flammable gas cloud behavior.

\section{Effect of Pool Ground Type}

Figure 3 shows a comparison between the flammable mass, flammable hydrogen cloud and LH2 pool size results predicted by FLACS for three pool model ground types - wet coarse sand, concrete and insulated (characterized in terms of thermal conductivity and thermal diffusivity values given in Table 4).

TABLE 4: POOL MODEL GROUND PROPERTIES

\begin{tabular}{lcc}
\hline Ground Type & $\begin{array}{l}\text { Thermal } \\
\text { Conductivity } \\
(\mathbf{W} / \mathrm{m} / \mathrm{K})\end{array}$ & $\begin{array}{l}\text { Thermal } \\
\text { Diffusivity } \\
\left(\mathrm{m}^{2} / \mathrm{s}\right)\end{array}$ \\
\hline Wet coarse sand & 3.72 & $1.45 \times 10^{-6}$ \\
Concrete & 1.1 & $1.0 \times 10^{-6}$ \\
Insulated & 0.0 & $10^{30}$ \\
\hline
\end{tabular}

Both concrete and particularly the wet coarse sand have a relatively high thermal inertia, meaning that the ground takes longer to cool and so maintains greater temperature difference and rate of heat transfer to the $\mathrm{LH} 2$ pool. Hence the higher level of heat transfer from the concrete and particularly for the wet sand produces a much greater level of vaporization of the LH2 pool (smaller maximum pool radius and shorter time to total vaporization), cloud dispersion and greater peak flammable mass and flammable extent but for a shorter duration. In contrast for the insulated pool, there is no heat transfer from the ground to the pool - which rapidly grows to the maximum size of the pool, thereafter resulting in a slow steady vaporization of the LH2 pool and producing a sustained long duration flammable cloud with a relatively low flammable mass and a smaller flammable extent.

\section{Effect of wind speed}

Figure 4 shows a comparison between the flammable mass and flammable hydrogen clouds predicted by FLACS for different wind speeds (on a wet sand ground type). At lower wind speeds the head of the cloud becomes buoyant rising away from the ground. At higher wind speeds the cloud becomes restricted to travelling along the ground, increasing the maximum downwind flammable distance and reducing the maximum flammable height reached. However, the level of dilution of the cloud also increases at higher wind speeds, with both the peak flammable mass and duration of the flammable cloud being reduced. This serves to limit the maximum flammable extent of the cloud. Thus, increasing the wind speed from $3.6 \mathrm{~m} / \mathrm{s}$ to 6.3 $\mathrm{m} / \mathrm{s}$ has only a small effect on the maximum downwind flammable distance reached by the cloud.
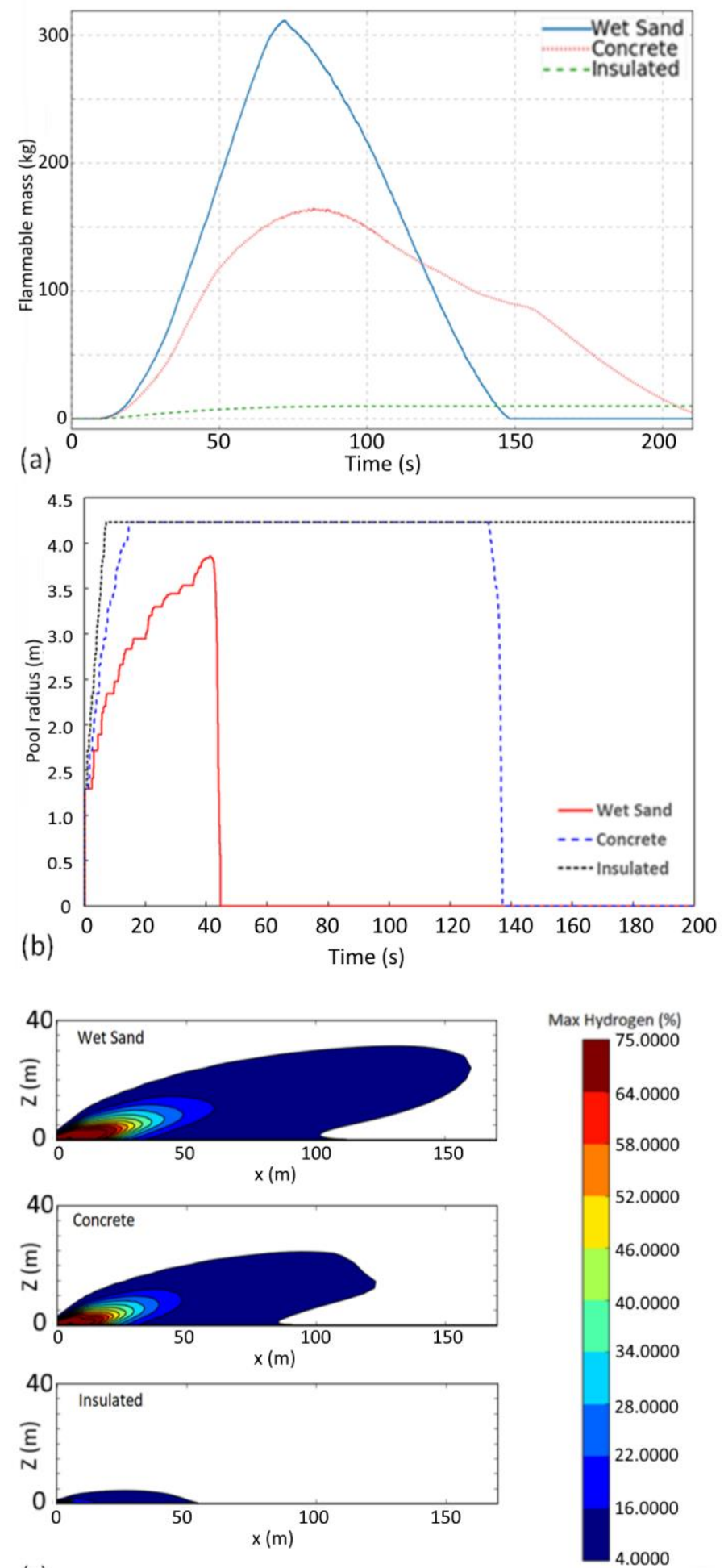

(c)
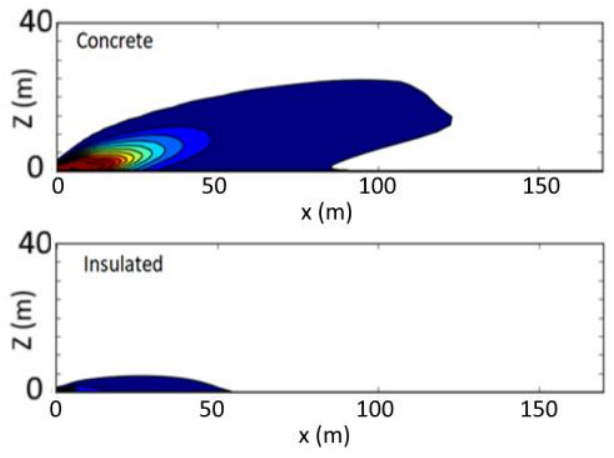

8.0000

.0000

.0000

FIGURE 3: EFFECT OF POOL GROUND TYPE ON THE PREDICTED RESULTS FOR: (A) FLAMMABLE MASS VERSUS TIME; (B) POOL RADIUS VERSUS TIME; (C) MAXIMUM HYDROGEN CONCENTRATION OF FLAMMABLE CLOUD. 


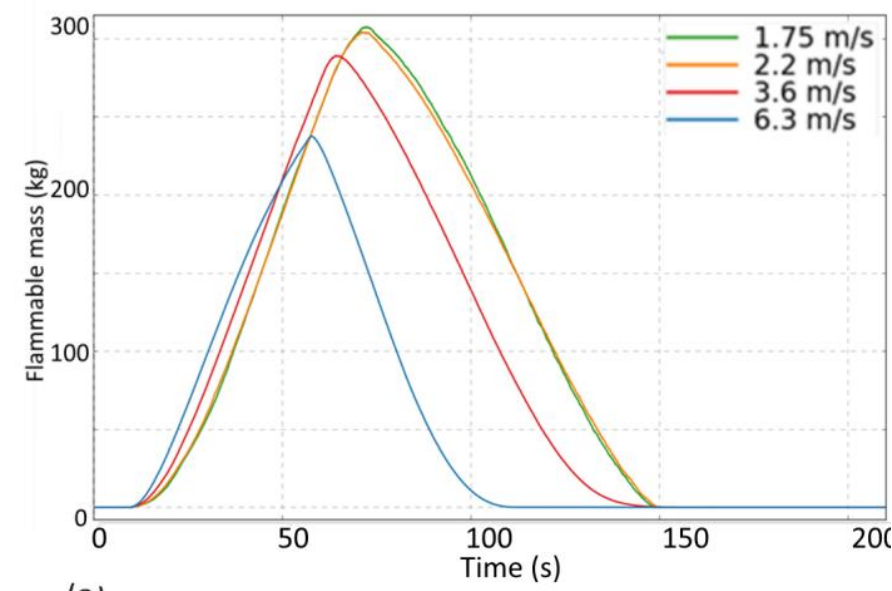

(a)
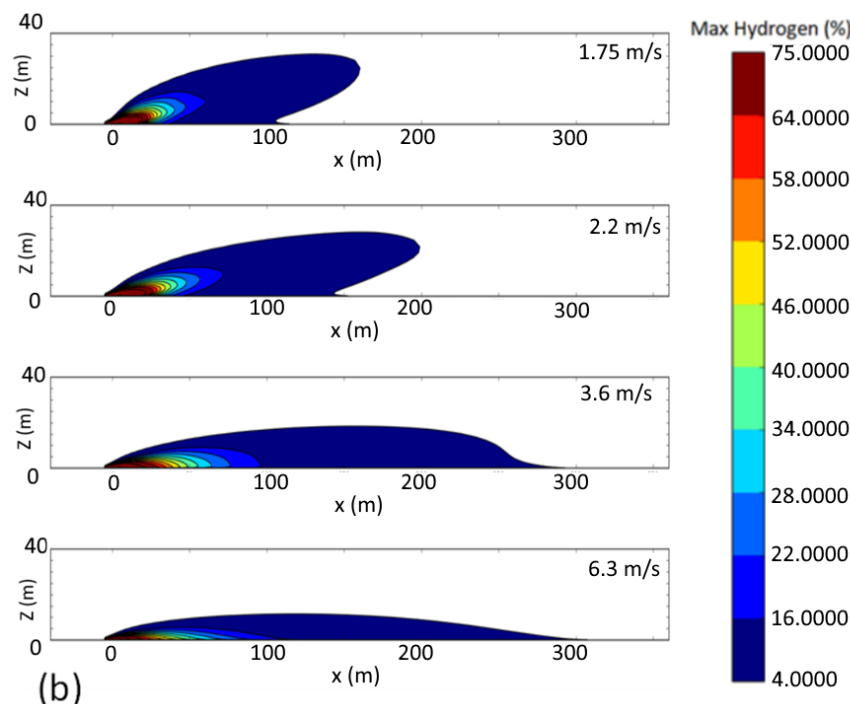

(b)

FIGURE 4: EFFECT OF WIND SPEED ON THE PREDICTED RESULTS FOR: (A) FLAMMABLE MASS VERSUS TIME; (B) MAXIMUM HYDROGEN CONCENTRATION CONTOUR PLOTS OF THE FLAMMABLE CLOUD.

\section{CONCLUSIONS}

This work combines multiple safety studies to explore the safety of liquid hydrogen fuel use for civil aviation. PHAs, utilizing over 70 sources, and in consultation with industry, are used to understand the hazards posed by liquid hydrogen use in civil aviation.

For risks at airport the area with the highest risk factor (product of severity and likelihood scores) has been identified as firefighting, with scores up to 25 (out of a possible 25). The scores are relatively high for both pre-and post-mitigation assessments due to considerable work required to provide new regulation and integrate firefighting techniques. Storage and on site generation risk scores are also relatively high (up to 9 average) however given there are existing methods to mitigate these hazards, following mitigation, risk factor averages fell to around 2. However, the range of these is wide given possible concerns over technology integration with new systems. Most fueling hazards could not be assessed post mitigation due to the level of technology development required.

Based on gaps relevant to multiple areas of aviation engineering highlighted by the PHA process, FLACS CFD modelling has been used in this work to simulate large scale LH2 pool releases to examine their behavior and predict the LH2 pool size, downwind distance to LFL, and flammable mass of the hydrogen-air clouds formed for different environmental conditions and release scenarios.

Using the model to examine the effect of different pool ground types, materials with a higher thermal conductivity (e.g. wet sand) were found to produce a cloud with a greater peak flammable mass and flammable extent, but for a shorter duration.

At lower wind speeds the head of the cloud becomes buoyant rising away from the ground, while at higher wind speeds the cloud becomes restricted to travelling along the ground, increasing the downwind flammable distance. However, the level of dilution of the cloud also increases with wind speed, serving to limit the maximum flammable extent reached by the cloud.

\section{FUTURE WORK}

It has been found that little work has explored the combination effects of pressure and temperature on hydrogen flammability. This will be addressed in future papers as part of this project.

One key area identified in both on-board systems and airport PHA as requiring further work was the analysis of releases of large volumes of liquid hydrogen. This was related to, inter alia, crash and damage scenarios, emergency release, and excessive boil-off in the event of delays. This paper has explored some large scale release issues, however far more work, both modelling, and ideally experimental (though the cost and complexity of this work makes the opportunity challenging) are needed to better understand the behavior of catastrophic or large hydrogen releases in a range of scenarios.

Other work identified as being required to introduce hydrogen specifically at airports included:

- Fuller analysis of airport fuel volume supply, storage and liquefaction

- Consideration on airport safety classifications, regulatory regime, and firefighting provision

- Fueling system designs

\section{ACKNOWLEDGEMENTS}

This project received funding from the European Union's Horizon 2020 research and innovation programme under Grant Agreement No. 769241.

\section{REFERENCES}

[1] European Commission (2011). Flightpath 2050 Europe's Vision for Aviation. European Commission. https://ec.europa.eu/transport/sites/transport/files/mod es/air/doc/flightpath2050.pdf. Last accessed 26/11/19 
[2] ICAO (2019) Environmental Report - Aviation and the Environment - Destination Green - The Next Chapter. https://www.icao.int/environmentalprotection/pages/envrep2019. aspx. Last accessed 26/11/19

[3] The Intergovernmental Panel on Climate Change(UN). Page summary for policymakers of IPCC special report on the impacts of global warming of $1.5^{\circ} \mathrm{C}$ approved by governments.

https://www.ipcc.ch/2018/10/08/ . Last accessed $26 / 11 / 19$

[4] Committee on Climate Change (2019). Net Zero: The UK's contribution to stopping global warming. Committee on Climate Change. May 2019. https://www.theccc.org.uk/publication/net-zero-theuks-contribution-to-stopping-global-warming/. Last accessed 26/11/19

[5] Milne, S, Chambers, K, Elks, S, Hussain, B, and McKinnon, S. (2019). https://es.catapult.org.uk/wpcontent/uploads/2019/06/ESC-Living-Carbon-Freereport-for-CCC.pdf. Last accessed 29/01/2020

[6] Gnadt, AR, Speth, RL, Sabnis, JS, and Barrett, SRH. 'Technical and environmental assessment of allelectric 180-passenger commercial aircraft' Progress in Aerospace Sciences Volume 105, February 2019, P 1-30

[7] Brewer, G (1991). Hydrogen Aircraft Technology, CRC Press.

[8] Cryoplane (2003). Final Technical Report (Publishable Version). September 2003. http://www.fzt.hawhamburg.de/pers/Scholz/dglr/hh/text_2004_02_26_Cr yoplane.pdf. . Last accessed 26/11/19

[9] Klebanoff, L.E., Pratt, J.W. and LaFleur, C.B., 2017. Comparison of the safety-related physical and combustion properties of liquid hydrogen and liquid natural gas in the context of the SF-BREEZE highspeed fuel-cell ferry. International Journal of Hydrogen Energy, 42(1), pp.757-774.

[10] ANSI/AIAA (2017). Guide to Safety of Hydrogen and Hydrogen Systems (ANSI/AIAA G-095A-2017). https://arc.aiaa.org/doi/abs/10.2514/4.105197.001. Last accessed 26/11/19.

[11] NFPA (2018). NFPA 2 Hydrogen Technologies Code. National Fire Protection Association. Quincy, MA.

[12] Rigas, F., \& Amyotte, P. (2012). Hydrogen safety. CRC Press.

[13] Khandelwal, B., Karakurt, A., Sekaran, P. R., Sethi, V., \& Singh, R. (2013). Hydrogen powered aircraft: The future of air transport. Progress in Aerospace Sciences, 60, 45-59.

[14] Benson, C. M., Ingram, J. M., Battersby, P. N., Mba, D., Sethi, V., \& Rolt, A. M. (2019, June). An analysis of civil aviation industry safety needs for the introduction of liquid hydrogen propulsion technology. In ASME Turbo Expo 2019: Turbomachinery Technical Conference and Exposition. American Society of Mechanical Engineers Digital Collection.

[15] Schmidtchen, U., Behrend, E., Pohl, H. W., \& Rostek, N. (1997). Hydrogen aircraft and airport safety. Renewable and sustainable energy reviews, 1(4), 239-269.

[16] Verstraete, D., Hendrick, P., Pilidis, P., \& Ramsden, K. (2010). Hydrogen fuel tanks for subsonic transport aircraft. International journal of hydrogen energy, 35(20), 11085-11098.

[17] Wierzba, I, Harris, K and Karim, G. "Effect of low temperature on the rich flammability limits in air of hydrogen and some fuel mixtures containing hydrogen," International Journal of Hydrogen Energy, vol. 17, no. 2, pp. 149-152, 1992.

[18] Panda, P and Hecht, E (2017) "Ignition and flame characteristics of cryogenic hydrogen releases,"

[19] Kuznetsov, M, Friedrich, A, Stern, G, and L'hostis, B. (2015). "Medium scale experiments on vented H2 deflagration," J. of Loss Prevention in Process Ind, pp. 416-428, 2015.

[20] Rehn, S. (2014). "DOT/FAA/TC-TT14/36 FLAMMABILITY OF HYDROGEN AT SUBATMOSPHERIC PRESSURES AND," Federal Aviation Administration, New Jersey.

[21] Kuznetsov, M., Kobelt, S., Grune, J., \& Jordan, T. (2012). Flammability limits and laminar flame speed of hydrogen-air mixtures at sub-atmospheric pressures. International journal of hydrogen energy, 37(22), 17580-17588.

[22] Jones, T (2009) Explosive nature of hydrogen in partial pressure vacuum. Heat Treat Prog (Jan.-Feb), pp. $43-46$

[23] ISO/IEC 80079-20-1:2017. Explosive atmospheres Part 20-1: Material characteristics for gas and vapour classification - Test methods and data. International Standards Organisation.

[24] BAA Heathrow (2012). https://www.fch.europa.eu/sites/default/files/project_r esults_and_deliverables/HyTEC\%20Heathrow\%20HR S\%20planning\%20report\%20\%28ID\%202849576\%29 .pdf. Created 18/05/2012. Last accessed 20/11/2019.

[25] Thomas, C. E., Barbour, J. P., James, B. D., \& Lomax, F. D. (2000). Analysis of Utility Hydrogen Systems and Hydrogen Airport Ground Support Equipment. Proceedings of the 1999 US DOE Hydrogen Program Review, Report No. NREL/CP570-26938. 
[26] Fontela, P, Soriab, A, Mielgoc, J, Sierrac, JF, Blasc, J, Gauchiad, L, Martíneze, JM. Airport electric vehicle powered by fuel cell. Journal of Power Sources. Volume 169, Issue 1, 10 June 2007, Pages 184-193

[27] IEA (2004). http://ieahydrogen.org/pdfs/CaseStudies/munich_airport.aspx. International Energy Association Hydrogen technology. Created 14/09/2004. Last accessed 20/11/2019.

[28] Smith, R. E. (2012). MIL-STD-882E.

[29] Hooker, P., Willoughby, D. B., \& Royle, M. (2011, September). Experimental releases of liquid hydrogen. In Proc. 4th Int. Conf. on Hydrogen Safety.

[30] Hall, J. E., Hooker, P., \& Willoughby, D. (2014). Ignited releases of liquid hydrogen: Safety considerations of thermal and overpressure effects. international journal of hydrogen energy, 39(35), 20547-20553.

[31] Ichard, M, Hansen, O, Middha, P, and Willoughby, D (2012) "CFD computations of liquid hydrogen releases," International Journal of Hydrogen Energy, vol. 37, pp. 17380-17389,.

[32] FLACS v10.8 User's Manual. GexCon AS; 2018.

[33] Hanna S.R., Hansen O.R., Dharmavaram S. FLACS air quality CFD model performance evaluation with Kit Fox, MUST, Prairie Grass, and EMU observations. Atmos Environ 2004; 38: 4675-87.

[34] Hansen O.R, Gavelli F, Ichard M, Davis S. Validation of FLACS against experimental data sets from the model evaluation database for LNG vapour dispersion. J Loss Prev Process Ind 2010; 23(6): 857-77.

[35] Middha P, Ichard M, Arntzen BJ. Validation of CFD modelling of LH2 spread and evaporation against large-scale spill experiments. Int J Hydrogen Energy 2011; 36:2620-7.

[36] Witcofski, R D, Chirivella, JE. Experimental and analytical analyses of the mechanisms governing the dispersion of flammable clouds formed by liquid hydrogen spills, Int J Hydrogen Energy 1984; 9(5):425-35. 